\title{
The Effect of Suggestedia Method on Students' Speaking Ability at Grade VIII MTsN Model Padangsidimpuan Lokasi Ujung Gurap
}

\author{
BY \\ Anggi Laila Dzikriah, S.Pd \\ Rayendriani Fahmei Lubis, M. Ag, Zainuddin, S.S.,M.Hum
}

\begin{abstract}
Penelitian ini berfokus pada pengaruh metode sugestopedia pada kemampuan berbicara siswa di kelas VIII MTsN Model Padangsidimpuan Lokasi Ujung Gurap. Masalah siswa dalam berbicara adalah: 1) siswa tidak dapat berbicara di kelas bahasa Inggris; 2) penguasaan kosakata siswa kurang dan siswa merasa sulit mengucapkan kata-kata; 3) siswa menjadi bosan dan merasa tidak tertarik dalam berbicara; 4) akhirnya, banyak siswa kurang motivasi dan perhatian untuk berbicara bahasa Inggris. Tujuan dari penelitian ini adalah untuk menguji apakah ada pengaruh yang signifikan Metode Suggestopedia pada Kemampuan Berbicara Siswa di Kelas VIII MTsN Model Padangsidimpuan Lokasi Ujung Gurap. Metode yang digunakan dalam penelitian ini adalah penelitian eksperimental. Populasi adalah siswa kelas VIII MTsN Model Padangsidmpuan Lokasi Ujung Gurap. Total populasi adalah 3 kelas. Dua kelas dipilih dengan cluster sampling. Mereka adalah VIII-11 (kelas eksperimen) dan VIII-12 (kelas kontrol). Itu diambil setelah melakukan uji normalitas dan homogenitas. Data berasal dari pre-test dan post-test. Untuk mengukur data, peneliti menggunakan rumus uji-t. Setelah menganalisis data, peneliti menemukan bahwa skor rata-rata kelas eksperimen setelah menggunakan metode sugestopedia lebih tinggi daripada kelas kontrol. Nilai rata-rata kelas eksperimen sebelum menggunakan metode suggestopedia adalah 62,6 dan kelas kontrol adalah 61,8. Kemudian, nilai rata-rata kelas eksperimen setelah menggunakan metode suggestopedia adalah 74.1 dan kelas kontrol adalah 65.6. Selain itu, skor t-hitung lebih besar dari t-tabel $(4,22>2,021)$. Ini berarti bahwa hipotesis alternative (Ha) diterima dan (H0) ditolak. Disimpulkan bahwa ada pengaruh yang signifikan Metode Suggestopedia pada Kemampuan Berbicara Siswa di Kelas VIII MTsN Model Padangsidimpuan Lokasi Ujung Gurap.
\end{abstract}

Key words: Suggestopedia Method, Students’ \& Speaking Ability

\section{A. INTRODUCTION}

Speaking is an interactive process of constructing meaning that involves producing and receiving and processing information. ${ }^{1}$ Henry Guntur Tarigan said speaking is the ability to pronounce sound articulation of words to express, to declare and to deliver the idea, feeling

${ }^{1}$ Kathleen M. Bailey, Practical Language Teaching Speaking, (Singapore: Mc Graw Hill, 2005), p.2 
or sense, as a large of this limitation we can say in speaking. ${ }^{2}$ Speaking is important to be learned and mastered be every individual. Therefore, students must have extensive knowledge if they want to write something and there were few reasons why speaking necessary in our life.

First, speaking is the process of building and sharing meaning thought in verbal and symbol of varieties in context, with use language we can to communication to other people. When someone speaks, they interact and use the language to express the idea, feeling and thought, they also shares about the information to order trough communication.

Second, speaking is to express oneself in life situations or the ability to reports acts or situations in precise words, or the ability to converse, or to express a sequence of ideas fluently. The ability is used in essentially normal communication situations the signaling system of pronunciation, stress, intonation, grammatical structure, and vocabulary of the foreign language at a normal rate of delivery for native speakers of the language.

Finally, speaking is one of the important communication tools to be able to declare themselves as member of the people. In teaching and learning, speaking is one of the most important skills. Speaking ability is a capability of do something and making a certain response physical or mental as well as gives a clear explanation about what the people says especially of the students.

Generally, speak English is one of the subject must be learn in every school in our country. It has been taught by students from elementary school, junior high school, and also in university. Many students thought that speaking is difficult, because speaking happens in real time, and speaking can't be edited and revised. It will be possible to do mistakes in pronunciation or grammar. In fact, whether the students have already learned language English especially students' ability in speaking is still far from expectation. This is known from researcher' teaching experience and based on private interview with teachers in MTsN Model Padangsidimpuan Lokasi Ujung Gurap. The teachers mentions some problems in students speaking they are;

First, many students were not able to speak in English class. It was because they felt shame when they were speaking, and they did not know what they will say after ordered to make a conversation in front of the class. Most students cannot explain and generate their

\footnotetext{
${ }^{2}$ Henri Guntur Tarigan, Berbicara Sebagai Suatu Keterampilan Berbahasa, (Bandung: Angkasa, 1986), p. 15
} 
statement and opinion. When they were express about the certain topic in English, they cannot describe it correctly. They had difficulties to express their ideas in English.

Second, many students were lack motivation and attention about the important of speaking, students were seldom to practice speaking with their friends because students' vocabulary mastery was less in memory and students difficult how to pronounce words. Then, the students got bored and uninterested in speaking because when the process of learning teachers just used conventional method and without media. Teachers teach just opening the book, read the conversation and just listen to what teachers reads. ${ }^{3}$

To solve the problem in speaking ability, there are alternative for teaching speaking activity that available and applicable. The teacher must know about the method in teaching and learning, because method in teaching and learning can influence the motivation of the students and it is also help the teacher able to teaching the students easily. The students can get motivation to follow the teaching and learning as well as possible to increase expectation in speaking English well.

Method is one of the important in teaching to improvement students speaking ability, teaching method is an organization and application of the teaching technique, teaching material, teaching aids and supplementary materials by the teacher with the aims of achieving the teaching and learning objectives. The method in teaching and learning process is a medium transferring knowledge between the teacher and students. Then, teaching method refers to the teaching way which gives direction to the teacher how to handle learning process.

To make students able in speaking, there are some methods that can be use in teaching. There are direct method, silent way method, audio lingual method, suggestopedia method and others. From some way for teaching speaking, the researcher chose suggestopedia method to solve the problem. While, Diane Larsen Freeman stated Suggestopedia is a teaching method which is based on a modern understanding of how the human brain works and how learn most effectively and the goals of teacher used suggestopedia is to accelerate the process by which students to use a foreign language for everyday communication. ${ }^{4}$ It is the reason for the researcher to do research.

\footnotetext{
${ }^{3}$ Private Interview, Teacher of English MTsN Model Padangsidimpuan Lokasi Ujung Gurap, (Padangsidimpuan, January $16^{\text {th }}$ 2017)

${ }^{4}$ Diane Larsen, Freeman Teaching And Principle In Language Teaching,( New York: Oxford University Press, 2000) p.81
} 


\section{B. THEORITICAL DESCRIPTION}

\section{General Concept of Speaking}

\section{a. Definition of Speaking}

Speaking is an interactive process of constructing meaning that involves producing and receiving and processing information. ${ }^{5}$ David Nunan states speaking is the productive aural/oral skill; it consists of producing systematic verbal utterances to convey meaning. ${ }^{6}$ Speaking is fundamentally an instrumental act. Speakers talk in order to have some effects on their listeners. ${ }^{7}$ So, it can be concluded that speaking is process to convey meaning by orally.

Speaking is a productive skill that can be directly and empirically observed, those observation are invariably colored by the accuracy and effective. ${ }^{8}$ Henry Guntur Tarigan said speaking is the ability to pronounce sound articulation of words to express, to declare and to deliver the idea, feeling or sense, as a large of this limitation we can say in speaking. ${ }^{9}$ Speaking is process to express idea from our mind to oral.

Speaking ability is to express oneself in life situations or the ability to report acts or situations in precise words, or the ability to converse, or to express a sequence of ideas fluently. The ability is used in essentially normal communication situations the signaling system of pronunciation, stress, intonation, grammatical structure, and vocabulary of the foreign language at a normal rate of delivery for native speakers of the language. ${ }^{10}$ Furthermore, speaking is so much a part of daily life that we take it for granted. The average person produces tens of thousands of

\footnotetext{
${ }^{5}$ Kathleen M. Bailey, Practical Language Teaching Speaking, (Singapore: Mc Graw Hill, 2005), p.2

${ }^{6}$ David Nunan, Practical English Language Teaching, (New York: Mc. Grown-Hill Companies Inc, 2003), p.48

${ }^{7}$ Clark and Clark, Psychology and Language, (New York: Harcourt Brace Jovenovich Inc, 1977), p. 223.

${ }^{8}$ Douglas Brown, Language Assessment Principle and Classroom Practice, (United States: Longman, 2004), p. 140 .

9 Henri Guntur Tarigan, Berbicara Sebagai Suatu Keterampilan Berbahasa, (Bandung: Angkasa, 1986), p. 15

${ }^{10}$ Robert Lado, Language Testing The Construction and Use of Foreign Language Tests, (USA: McGraw Hill Book Company, 1961), p.240-241.
} 
words a day, although some people-like auctioneers or politicians-may produce even more than that.

\section{General Concept of Suggestopedia Method}

\section{a. Definition Suggestopedia}

Suggestopedia is modern method which develops in 1970's by Bulgarian doctor, psychotherapist and educator George Levanoz. Suggestopedia is derived from suggestology, as a science that concerned with the systematic study of the non rational and or non conscious influence. ${ }^{11}$ Suggestology is method has develops a right brain instructional strategy. The idea is to relax the resistance to language acquisition that comes from the critical thinking of the left hemisphere. ${ }^{12}$ It means suggestopedia can make students optimal the left and right brain to build their concentrate, imagination in learning and recall the memorization.

Suggestopedia is teaching systems which make use of all the possibilities tender suggestion can offer. Of course, the systematic academic participation is not neglected but is always in accord with the suggestive. ${ }^{13}$ Suggestopedia is the application of the study of suggestion to pedagogy, has been develop to help students eliminate the feeling that they cannot be successful or negative association they may have toward studying and, thus, to help them overcome the barriers for learning. ${ }^{14}$ While, suggestopedia is a method to make students relaxed and fun by using music, games, and poster in learning process with the positive suggestion to create learning effectively.

There are some advantages and in utilizing suggestopedia:

1) A comprehensible input based on dessugestion and suggestion principle. By using this suggestopedia method, students can lower their un confidence. Suggestopedia classes, in addition, are held in ordinary rooms with comfortable chairs, a practice that may also help them relaxed.

2) Authority concept. Students remember best and are most influenced by information coming from an authoritative source, teachers.

\footnotetext{
${ }^{11}$ Earl W. Stevick, Memory, Meaning and Method, (USA: New Burry House, 1976), p.42

12 James J. Asher, Learning Another Language Through Action the Complete Teachers' Guide Book, (California: Sky Oaks Production, 1983), p.28

${ }^{13}$ George Levanoz, Suggestopedia-Desuggesting Teaching Of Communicative Method On The Level Of The Hidden Reserves Of The Human Mind, (New York: Gordon and Breach, 1978) p. 11

14 Diane Larsen, Freeman Teaching And Principle In Language Teaching,( New York: Oxford University Press, 2000) p.73
} 
3) Peripheral learning. Suggestopedia encourages the students to apply language more independently, takes more personal responsibility for their own learning and get more confidence. ${ }^{15}$

\section{General Concept of Conventional Method}

\section{a. Definition of Conventional Method}

Conventional methods are thought to be traditional methods. However, they can be found in a daily teaching practice and other new methods originated from them. ${ }^{16}$ Conventional method is habitual teaching method used by teacher in classroom. The process of teaching is traditional and can make the students boring.

\section{b. Classification of Conventional Method}

Conventional method has many teaching method that we can used in teaching and learning process. Conventional method can divide into some method such as: lecturer, project, discuss, problem solving, homework, demonstrations and so on. ${ }^{17}$ From that method, there is the method that is often used by the teacher, such as lecturer method.

\section{RESEARCH METHODOLOGY}

This research was done at MTsN Model Padangsidimpuan Lokasi Ujung Gurap, it is located Jl. Besar Abdul Haris Nasution Ujung Gurap Kec. Batunadua. The schedule of this research is from October 2016 up to October 2017.

The researcher chose two classes as a sample. They are divided into experiment class and control class. The researcher used cluster sampling to take the sample. So the researcher took two classes as a sample of the research they were; VIII-11 which consist of 27 students and VIII-12 which consists of 24 students. The total of the sample were 51 students. To determine appropriate sample, it was tested by using normality and homogeneity test.

\section{FINDINGS}

In pre-test for experimental class, the researcher calculated the result the total score of experiment class in pre-test was 1620 , mean was 62.1 , standard deviation was 8.6, variant

\footnotetext{
15 Nova Eka Sari, Advantage and Disadvantages of Suggestopedia Method, accessed from http:// .wordpress.com/2011/06/12/a-teaching-method-suggestopedia, retrieved 15 November 2016

16 Karolina Lesiak, Teaching English to Adolescent, accessed from http://www.wordl scientificnews.com/wp-content/upload/2015/06/WSN-7-2015-246-260.pdf, retrieved 8 Mei 2017

${ }^{17}$ Syaiful Bahri Djamarah, Strategi Belajar Mengajar, (jakarta: PT, Asdi Maharsya, 2006) p.23
} 
was 76.30 , median was 59.7 , range was 32 , modus was 60 , interval was 5 . The researcher got the highest score was 76 and the lowest score was 44 . The total score of control class in pretest was 1440 , mean was 61.8 , standard deviation was 8 , variant was 64 , median was 60 , range was 32 , modus was 60 , interval was 5 . The researcher got the highest score was 76 and the lowest score was 44. It can be seen on appendix 5. And the total score of experiment class in post-test was 1940, mean was 74.1, standard deviation was 7.35, variant was 57.20, median was 72.2 , range was 28 , modus was 73 , interval was 5 . The researcher got the highest score was 84 and the lowest score was 56.

After calculated the data of post-test, researcher has found that post-test result of experiment and control class is normal and homogenous. Based on the result, researcher used parametric test by using T-test to analyze the hypothesis. Hypothesis alternative $\left(\mathrm{H}_{\mathrm{a}}\right)$ of the research was "There was the significant effect suggestopedia on students' speaking ability at grade VIII MTsN Model Padangsidimpuan Lokasi Ujung Gurap”. The calculation can be seen on the (appendix 9 and 10).

The test hypothesis has two criteria. First, if $t_{\text {count }}<t_{\text {table, }}, H_{0}$ is accepted. Second, $t_{\text {count }}>t_{\text {table }}, H_{a}$ is accepted. Based on researcher calculation, researcher found that $t_{\text {count }} 4.22$ while $\mathrm{t}_{\text {table }} 2.021$ with opportunity $(1-\alpha)=1-5 \%=95 \%$ and $\mathrm{dk}=\mathrm{n}_{1}+\mathrm{n}_{2}-2=27+24-2=$ 49. Cause $t_{\text {count }}>t_{\text {table }}(4.22>2,021)$, it means that hypothesis $H_{a}$ is accepted and $H_{0}$ was rejected. So, there was the effect suggestopedia method toward students speaking ability at grade VIII MTsN Model Padangsidimpuan Lokasi Ujung Gurap. It described the mean score of experimental class by using suggestopedia was 74.1 and the mean score of control class by using conventional method was 65.6. so from the explanation above that students' speaking ability by using suggestopedia method was better than using conventional strategy. Then there was significant effect toward students speaking ability by using suggestopedia method at grade VIII MTsN Model Padangsidimpuan Lokasi Ujung Gurap.

Based on data analysis above, it has proven that the suggestopedia method significant on students' speaking ability. Meanwhile the principles of suggestopedia method is teachers hope to accelerate process by which student learn to used foreign language for every day communication. According to George Lezanov Suggestopedia is derived from suggestology, as a science that concerned with the systematic study of the non rational and or non conscious 
influence. ${ }^{18}$ Suggestopedia method also sees that the four skills: speaking, listening, reading and writing reinforce each other but oral communication is seen basically.

According to related finding, Tri Anggono Sulistiono said suggestopedia suitable to teaching speaking, suggestopedia teaching method stress the teaching process using comfortable environment. It means that in learning process teacher should build up the confidence of the students to master the material so that students will set free their mind in doing the activity in classroom. ${ }^{19}$ Moreover in learning speaking, students can easily practice their speaking in comfortable environment without any feeling worry about making mistakes in classroom.

Then, Wahyu Erwanto said uses suggestopedia method was improve the student' speaking ability. suggestopedia method emphasizes the relaxation atmosphere during the application of teaching learning process so that the use of music and oral guidance from the teacher is highly used. suggestopedia has elements that can be used successfully to teach speaking for young learners and has a positive and consistent effect to students' critical thinking skills immediately after treatment. ${ }^{20}$

This proof show that suggestopedia method is suitable to be applied in teaching speaking because it has been proven by the previous researcher and the theory. So, suggestopedia method has given the significant effect to the research that has been done by the researcher or the other researcher who mentioned in related finding.

\section{E. CONCLUSION}

Based on the result of the research, the conclusions of this research are:

1. The students' speaking ability before using suggestopedia method at grade VIII MTsN Model Padangsidimpuan Lokasi Ujung Gurap was low. Before using suggestopedia method, the mean score of experimental class was 62.6.

2. After using suggestopedia method, the mean score of experimental class was 74.1. After using suggestopedia method students speaking ability increased.

\footnotetext{
${ }^{18}$ Earl W. Stevick, Memory, Meaning and Method, (USA: New Burry House, 1976), p.42

${ }^{19}$ Tri Anggono Sulistiono "The Effectiveness of Using Suggestopedia Method in Teaching Speaking at Grade $X$ of SMA Negeri 1 Kayen, (Semarang: UNNES, 2011), accessed from http://lib.unnes.ac.id/959/1/6991.pdf retrieved Mei 18th, 2017

${ }^{20}$ Wahyu Erwanto, Improving the Speaking Ability of the Seventh Grade Students of MTsN 01 Kudus Taught by Using Suggestopedia Method in Academic Year 2013/2014, (Kudus: Universitas Muria Kudus 2014) accessed from, http://eprints.umk.ac.id.3606/1/Hal judul.pdf retrieved Mei 18th, 2017
} 
3. The result of the research showed that the students' score in experimental class was higher than control class. The result provide that $t_{0}$ was higher than $t_{t .,} t_{0}$ was $4.22 t_{t}$ was $2.021(4.22>2.021)$ it means that there was a significant effect of using suggestopedia method on students' speaking ability at grade VIII MTsN Model Padangsidimpuan lokasi Ujung Gurap, where $\mathrm{H}_{a}$ was accepted and $\mathrm{H}_{0}$ was rejected.

\section{REFERENCES}

Asher, James J, Learning Another Language Through Action The Complete Teachers' Guide Book, (California: Sky Oaks Production, 1983)

Bambang Setiadi, Teaching English As a Foreign Language, (Yogyakarta: Graha Ilmu, 2006)

Bailey, Kathleen M, Practical Language Teaching Speaking, (Singapore: Mc Graw Hill, 2005)

Brown, Doughlas, Teaching by Principles: An interactive approach to language pedagogy (New Jersey: Englewood Cliffs, 1994)

Clark \& Clark, Psychology and Language, (New York: Harcourt Brace Jovenovich Inc, 1977)

Daryanto, Strategi dan Tahapan Mengajar, (Bandung: CV Yrama Widya, 2013)

Donough, Joe Mc, Material and Methods in ELT (A Teacher's Grade Cambridge: Blackwell, 2003)

Gay, L.R \& Peter Airasian, Educational Research for Analysis and Application, (America: Prentice Hall, 1992)

Harmer, Jeremi, The Practice Language Teaching, (London: Longman, 2001)

Hornby, A.S Oxford Learner's Pocket Dictionary, (New York: Oxford University Press, 2008)

Hughes, Arthur, Testing for Language Teachers, (London: Cambridge University Press, 2003)

Jonathan Newton, I.S.P Nation, Teaching ELS/ELF Listening And Speaking, (New York: Routledge, 2009)

Lado, Robert, Language Testing: The Construction and Use of Foreign Language Tests, (USA: Mc Graw Hill Book Company, 1961)

Larsen, Freeman Diane Techniques an Principles in Language Teaching, (New York: Oxford University Press, 2000)

Levanoz, George, Suggestopedia-Desuggesting Teaching of Communicative Method on The Level Of The Hidden Reserves Of The Human Mind, (NewYork: Gordon and Breach, 1978) 
Mardalis, Metode Penelitian:suatu pendekatan proposal (Jakarta: Bumi Aksara,2003)

Neufeldt, Victoria, Webster New World College Dictionary-3 Rd, (New York: Simon \& Schuster Inc, 1995)

Nunan, David, Practical English Language Teaching, (Singapore: Mc. Graw Hill, 2003)

Richard, Jack \& Theodore S. Rogers Approaches and Method in Language Teaching: a description analysis, (New York: Cambridge University Press, 2001)

Stevick, Earl W, Memory, Meaning and Method, (USA: Newburry house, 1976)

Syaiful Bahri Djamarah Strategi Belajar Mengajar, (Jakarta: PT, Asdi Maharsya, 2006)

Tarigan, Henry Guntur, Berbicara Sebagai Suatu Keterampilan Berbahasa, (Bandung: Angkasa, 1986)

Jeff, A Critical Review of Suggestopedia accessed from http://jeffstar.blog.sohu.com/43920795.html, retrieved 18 Mei 2017

Karolina Lesiak, Teaching English to Adolescent, accessed from http://www.wordl scientificnews.com/wp-content/upload/2015/06/WSN-7-2015-246-260.pdf, retrieved 8 Mei 2017

Nova Eka Sari, Advantage and Disadvantages of Suggestopedia Method, accessed from http:// .wordpress.com/2011/06/12/a-teaching-method-suggestopedia, retrieved 15 November 2016

Tami Asriani, The Effectivness by Using Suggestopedia Method on Students Reading Comprehension in Narrative Text (A Quasi Experimental Study at Third Grade Students of MTsN II Pamulang, (Jakarta: UIN Syarif Hidayatullah, 2015), accessed from

http://repository.uinjkt.ac.id/space/bitsream/123456789/29606/3/TAMI\%20Asrianiftik.pdf retrieved Mei $18^{\text {th }} 2017$

Tri Anggono Sulistiono "The Effectiveness of Using Suggestopedia Method in Teaching Speaking at Grade X of SMA Negeri 1 Kayen, (Semarang: UNNES, 2011), accessed from http://lib.unnes.ac.id/959/1/6991.pdf retrieved Mei 18th 2017

Wahyu Erwanto, Improving the Speaking Ability of the Seventh Grade Students of MTsN 01 Kudus Taught by Using Suggestopedia Method in Academic Year 2013/2014, (Kudus: Universitas Muria Kudus 2014) accessed from, http://eprints.umk.ac.id.3606/1/Hal judul.pdf retrieved Mei 18th, 2017 